\section{Bases Sociais do Recrutamento Político no Sistema Partidário Brasileiro}

Leôncio Martins RODRIGUES. Partidos, ideologia e composição social: um estudo das bancadas partidárias na câmara dos deputados. São Paulo, Edusp, 2002. 242 páginas.

\section{Maria D'Alva Kinzo}

A experiência partidária tem sido um dos campos de estudo mais promissores na ciência política brasileira. Apesar de existir há menos de dezoito anos, o sistema partidário brasileiro já foi objeto de uma gama de estudos e alvo de um controverso debate acadêmico acerca de suas fragilidades e virtudes. Ao contrário do que se passou com o sistema partidário de 1945-1964, cujo estudo se tornou relevante somente após sua derrocada, o presente sistema já foi alvo de teses conclusivas antes mesmo de ter sua configuração definida.

Este renovado interesse pelo conhecimento da questão partidária é, sem dúvida, indicativo de uma maior valorização das instituições típicas da democracia representativa. É indicativo também da institucionalização da ciência política no Brasil como um ramo distinto nas ciências sociais. Tratase de uma área do conhecimento dos fenômenos políticos tomados, não como mero reflexo dos processos sociais e econômicos, mas como produto da dinâmica do sistema político, de instituições e atores que movem a ação política e o jogo de poder. Este fator deve ter sido o responsável pelo desenvolvimento tão rico dos estudos sobre os partidos e o sistema partidário no Brasil. Talvez seja também por isso - em face da maior ênfase no recorte estritamente político - que os estudos recentes sobre a problemática partidária tenham deixado para segundo plano um dos aspectos fundamentais da análise, qual seja, o exame das bases sociais da ação política. Embora o sistema político se mova por uma dinâmica própria, que envolve atores individuais e coletivos, organizados e não-organizados, jogando de acordo com de- terminadas regras, está inserido no jogo de interesses sociais que, de alguma forma, ganham expressão por meio dos canais de representação política.

Assim, o estudo dos partidos e do sistema partidário não pode prescindir de análises que se preocupam com o componente societal, no que tange tanto às bases sociais de apoio eleitoral aos partidos como ao perfil social daqueles que constituem a representação político-partidária nas esferas de poder político. É esta a contribuição mais importante do livro de Leôncio Martins Rodrigues, Partidos, ideologia e composição social: examina a problemática partidária sob um ângulo pouco explorado pelos estudos recentes, qual seja, as bases sociais do recrutamento político no atual sistema partidário.

$\mathrm{O}$ autor introduz essa temática por meio de uma revisão da literatura sobre o presente sistema partidário, expondo os dois lados da controvérsia que se constituiu em torno do diagnóstico sobre essa experiência: de um lado, uma visão mais pessimista, que aponta o caráter instável e frágil do sistema partidário e seus possíveis problemas para a governabilidade democrática; de outro, uma visão mais otimista, que salienta a existência de padrões próprios de uma situação partidária estável e forte no que tange a sua capacidade de dar sustentação a governos e de representar as diferentes correntes ideológicas. Ao revisar a literatura sobre o tema, Martins Rodrigues não teve por objetivo, no entanto, se colocar em um dos lados do debate. $\mathrm{Na}$ verdade, embora concorde com a avaliação mais positiva, se nega a assumir uma posição de crítica contundente ao diagnóstico pessimista, ressaltando o caráter conjuntural de tais análises, fruto muitas vezes da avaliação de uma experiência em sua fase inicial. Seu intuito foi definir em torno de quais parâmetros deveriam situar sua análise. A meu ver, dois seriam eles: o primeiro é o de que o sistema partidário brasileiro está se consolidando segundo alguns padrões definidos, e o segundo, de que a composição socioprofissional da representação político-partidária é uma variável relevante na caracterização dos partidos, distinguindo-os especialmente quando posicionados na escala esquerda-direita.

O estudo trata, portanto, de demonstrar que o sistema partidário brasileiro está em processo de estruturação, o que se observaria não apenas atra- 
vés da análise dos padrões de apoio eleitoral aos partidos nas três últimas eleições legislativas apoio este que assume várias formas nos diversos contextos regionais - mas, sobretudo, através do exame do tipo de recrutamento social dos representantes partidários. Trata-se de mostrar que o recrutamento das lideranças partidárias segue um padrão que tem a ver com características sócioocupacionais e ideológicas, significativas o suficiente para diferenciar os partidos tanto em termos ideológicos como em termos do perfil social predominante de seus representantes no Legislativo. Reside aí a contribuição original deste estudo.

Para desenvolver tal análise, além dos resultados das três ultimas eleições para a Câmara dos Deputados, o autor se utiliza de dados biográficos dos deputados eleitos em 1998 (51 ${ }^{\text {a }}$. Legislatura) compilados pelo Centro de Documentação e Informação da Câmara dos Deputados, bem como dos dados patrimoniais dos deputados segundo sua Declaração de Bens à Receita Federal. Vale destacar a importância da utilização desses dados não só por possibilitar uma definição detalhada da composição social das lideranças partidárias - oferecendo inclusive uma classificação das profissões bastante útil para pesquisas posteriores -, mas também por abrir uma linha de pesquisa antes inexplorada, qual seja, o exame da documentação que os candidatos apresentam à Justiça Eleitoral quando do registro de sua candidatura.

Talvez uma das objeções que se poderia fazer a este estudo esteja relacionada à seleção dos partidos. Para mostrar a existência de uma "relação consistente entre meios sócio-ocupacionais de recrutamento partidário" e a localização dos partidos no espectro ideológico direita-centro-esquer$\mathrm{da}$, o autor inclui apenas seis partidos: dois de direita (PPB e PFL), dois de centro (PMDB e PSDB) e dois de esquerda (PT e PDT). Ao se limitar a estes, seu estudo deixa de lado o PTB, a despeito de preencher um dos critérios utilizados para a seleção - o mínimo de 5\% da representação na Câmara. A justificativa baseia-se na escolha de um segundo critério para a inclusão dos partidos na análise: a presença de "perfil programático-ideológico relativamente consistente e nítido", o que não haveria no caso do PTB. Podemos até concor- dar que o PTB esteja longe de preencher tal critério - embora, a rigor, poder-se-ia afirmar o mesmo para o caso do PMDB. O problema, no entanto, é o fato de se ter excluído um partido por não ter perfil ideológico nítido e consistente em uma análise que pretende verificar justamente a presença de relação entre posicionamento ideológico e posição social da representação partidária. Ou a relação existe levando em conta todos os partidos relevantes no sistema partidário, ou não existe ou se trata de uma fraca associação. O fato de não se considerar todos os partidos relevantes acabou enfraquecendo a conclusão de que o sistema partidário tenha se estruturado de forma consistente no que tange ao posicionamento na escala esquerdadireita. Isto não invalida, no entanto, a interessante caracterização do perfil social de cada um dos seis partidos selecionados, apresentada com detalhe ao longo dos capítulos 3, 4 e 5. Tampouco diminui a qualidade de mais esta importante contribuição de Leôncio Martins Rodrigues, que se destaca pelo rigor analítico, pelo compromisso com a precisão científica e pela clareza e simplicidade na forma de expor seus argumentos e conclusões.

\section{MARIA D'ALVA KINZO é professora do Departamento de Ciência Política da Universidade de São Paulo.}

